\title{
Involvement of Farm Women in Watershed Activities - A Study in Odisha
}

\author{
J. K. Pati* and R. N. Das \\ Department of Extension Education, College of Agriculture, OUAT, Bhubaneswar, India \\ *Corresponding author
}

Keywords

Involvement,

Watershed, Women

programme,

Implementation

Article Info

Accepted:

20 August 2019

Available Online:

10 September 2019

\section{A B S T R A C T}

Watershed development programme placed a central emphasis on capacity building of the stakeholders and their active participation particularly women on planning, implementation and post project maintenance with primary goal of livelihood security. A study conducted with192 watershed women from 24 watersheds in four blocks of Sundargarh and Keonjhar districts of Odisha revealed that the watershed women had a favourable opinion for the involvement of Project personnel working at field level. But their involvement had been restricted with programme implementation and fund utilization only. The District Advisory Committee and Project Implementation Agency have to sensitize the project personnel and watershed women for their active involvement in decision making process, developing own programme, discussion on post project activities, monitoring and evaluation of progress, decision on post project activities, record keeping, input arrangement and optimum use of created assets for sustainable livelihood and empowerment.

\section{Introduction}

Watershed is an area of land that contributes runoff to a common point and claimed to be the most scientific unit for efficient management of land and water resources as it is an agro-climatic unit with relatively more homogeneity of land as well as other resources (Jaiswal et.al.1985). Watershed management is a holistic approach that aims at optimizing the use of land, water and vegetation in an area to alleviate drought, mitigate floods, prevent soil erosion, and improve water availability as well as increase fuel, fodder and agricultural production on sustained basis. (Oswal,1999). The Ministry of Rural Development, Government of India has formulated a guideline for effective implementation of National watershed Development Programme since 1995.

The principal objective of the programme is to promote sustainable livelihoods and diversifying livelihood options particularly for 
women and ensuring equal opportunities for them to ensure mainstreaming of gender equity.

Participation and involvement of people including women is pre requisite for effective implementation of the programme. Their participation should start from the collection of data on available resources, implementation, monitoring as well as follow up of the activities already executed (Thomas, 2010). The guideline placed a central emphasis on capacity building of the stakeholders and their active participation starting from planning, implementation and post project maintenance with the primary goal of livelihood security (Pandey and Singh 2014). Women constitute half of the population and their contribution is very much essential in development of family.

The guidelines have therefore emphasized for adequate vocational activities for women including capacity building programme for their sustainable income. Unless women are sensitized sufficiently and involve fully in the implementation process sustainable and substantial income will not be possible. The present study entitled was designed to analyze the extent of involvement of farm women in various watershed activities".

\section{Materials and Methods}

The study was undertaken in two tribal districts of Odisha in 2018.Two blocks i.e. Sundargarh Sadar and Lathikata in Sundargarh district as well as Jhumpura and Champua in Keonjhar,were randomly selected. Eight women farmers from among the watershed committee members, Self Help Groups,User groups and landless families were randomly selected as the respondents for the study having total sample size of 192.

The data collected on scale point of fully, partially and not involved in various activities were analysed with the score value of 3,2 and 1 respectively. Statistical tools such as mean score, rank order, gap percentage and path analysis were employed to reveal the results.

\section{Results and Discussion}

Success of the watershed Development Programme depends largely on the interest of the officials implementing the programme. The respondents of both the districts had favourably opined (Table-1) for the involvement of watershed executive committee members, Watershed Development Team (WDT) members, watershed volunteers and secretary of the watershed committee. Favorable opinions were not observed on involvement of district advisory committee, Project Implementing Agency and president of the watershed association. However, the data in the table as a whole indicated that the respondents had favorably opined for the involvement of the project personnel in the process of programme implementation.

Watershed Development programme is purely participatory with emphasis on bottom up planning and top down approach. Therefore, involvement of people particularly women have to involve actively in various activities. As observed from the Table.2, the respondents had better involvement in programme implementation and fund utilization. The watershed women have to involve fully in agro-ecological survey, problem identification and programme development in order to develop feasible and adequate programme for their income and employment generation. It is apprehended that the watershed officials formulate the programme and respondents were implementing. It is therefore suggested that the watershed officials have to involve women in all the processes to develop feasible and realistic programme towards income and employment generation leading to 
empowerment. Decision making is another important activity where watershed women have to be actively involved for developing feasible programme and successful implementation. Therefore, involvement of watershed women are very much essential in constraint analysis, need identification, selection for farmers training which were not being observed (Table-3). Better involvement in fund utilization, programme development and implementation indicated that the watershed women were simply implementing the programme designed by the project officials.

Involvement of watershed women in programme formulation could facilitate in developing adequate and feasible programme for them their employment and income generation. They need to be actively involved in agro-ecological survey through participatory rural appraisal (PRA) tools, discussion on their needs,problem diagnosis, prioritization and assessing interventions as well as developing both own and programming on government land. Poor involvement of the respondents observed (Table-4) on these aspects indicated that the watershed women were not involved in all these processes of programme formulations. Hence, it is doubtful for developing feasible and adequate programme for the women in watershed areas.

Programme implementation is the sole responsibility of the watershed women either of user groups, self-help groups or any socioeconomic backward communities. The women will receive the funds from watershed association and implement the approved programme. This may be the facts for which the respondents had better involvement (Table-6) in undertaking the activities as per the approved programme and arrangement of required inputs. Poor involvement observed on discussion on post project activities, evaluation, pleading for refinement or modification of the approved programme as per suitability, keeping records of each activities for further analysis and reviewing the progress of work time to time indicate their non-participation in planning as well as decision making process.

The guideline clearly envisages for regular monitoring and evaluation of the day to day activities involving project personnel and beneficiaries. It will help to solve the problems encountered in the field situation as well as effective implementation to achieve the end results. But, the study reveals for the poor involvement of the respondents on various aspects of monitoring and evaluation process as mentioned in Table-6. Many a times additional inputs are required for effective implementation of the programme. Crop diversification and new technologies introduction are very much essential to increase production.

Record maintenance, evaluation and suggestive measures help in assessing the performance for further action.Poor responses observed on these aspects indicate for the poor involvement of watershed women in monitoring and evaluation activities. Comparative analysis mentioned in Table -7 had indicated for the significant gaps on all the aspects of involvements covered under study.

Maximum percentage of gaps were observed on programme formulation $(55.00 \%)$ followed by programme implementation (49.00\%), monitoring and evaluation (40.33\%)as well as involvement of project personnel (27.33\%). The District advisory committee have to analyze for the poor involvement of women on the watershed development programme and sensitize the project personnel to involve the watershed women actively enabling them to plan adequate programme and implement effectively for generation of employment and income. 
Table.1 Involvement of the project personnel

\begin{tabular}{|l|l|l|l|l|l|}
\hline $\begin{array}{l}\text { S. } \\
\text { No. }\end{array}$ & Personnel & $\begin{array}{l}\text { Mean Score } \\
\text { Sundargarh } \\
(\mathbf{n = 9 6})\end{array}$ & $\begin{array}{l}\text { Keonjhar } \\
(\mathbf{n = 9 6})\end{array}$ & $\begin{array}{l}\text { Pooled score } \\
(\mathbf{n = 1 9 2})\end{array}$ & \\
\hline $\mathbf{1 .}$ & PIA & 2.12 & 1.98 & 2.06 & VI \\
\hline $\mathbf{2 .}$ & WDT Member & 2.55 & 2.64 & 2.60 & II \\
\hline $\mathbf{3 .}$ & Watershed Volunteers & 2.46 & 2.28 & 2.37 & III \\
\hline $\mathbf{4 .}$ & President of the watershed committee & 2.25 & 2.13 & 2.09 & V \\
\hline $\mathbf{5 .}$ & $\begin{array}{l}\text { Member of the watershed executive } \\
\text { committee }\end{array}$ & 2.60 & 2.78 & 2.69 & I \\
\hline 6. & District advisory committee & 1.01 & 1.28 & 1.14 & VII \\
\hline $\mathbf{7 .}$ & Secretary of Watershed committee & 2.25 & 2.43 & 2.34 & IV \\
\hline & & \multicolumn{3}{|c|}{ (Maximum obtainable score-3) } \\
\hline
\end{tabular}

Table.2 Involvement in watershed activities

\begin{tabular}{|l|l|l|l|l|l|}
\hline $\begin{array}{l}\text { S. } \\
\text { No. }\end{array}$ & Activities & $\begin{array}{l}\text { Mean Score } \\
\text { Sundargarh } \\
(\mathbf{n = 9 6})\end{array}$ & $\begin{array}{l}\text { Keonjhar } \\
(\mathbf{n = 9 6})\end{array}$ & $\begin{array}{l}\text { Pooled score } \\
(\mathbf{n = 1 9 2})\end{array}$ & \\
\hline $\mathbf{1 .}$ & Agro-ecological survey & 1.34 & 1.49 & 1.42 & V \\
\hline $\mathbf{2 .}$ & Problem identification & 1.77 & 1.65 & 1.71 & IV \\
\hline $\mathbf{3 .}$ & Programme development & 1.95 & 2.07 & 2.01 & III \\
\hline 4. & Programme implementation & 2.52 & 2.39 & 2.46 & I \\
\hline $\mathbf{5 .}$ & Fund utilization & 2.45 & 2.43 & 2.44 & II \\
\hline 6. & Evaluation of progress & 0.96 & 1.02 & 0.99 & VI \\
\hline
\end{tabular}

(Maximum Obtainable Score -3)

Table.3 Involvement in decision making process

\begin{tabular}{|l|l|l|l|l|l|}
\hline $\begin{array}{l}\text { S. } \\
\text { No. }\end{array}$ & Decision Making & $\begin{array}{l}\text { Mean Score } \\
\text { Sundargarh } \\
(\mathbf{n = 9 6 )}\end{array}$ & $\begin{array}{l}\text { Keonjhar } \\
(\mathbf{n = 9 6})\end{array}$ & $\begin{array}{l}\text { Pooled score } \\
(\mathbf{n = 1 9 2})\end{array}$ & \\
\hline $\mathbf{1 .}$ & Need identification & 2.07 & 2.13 & 2.10 & IV \\
\hline $\mathbf{2 .}$ & Programme development & 2.43 & 2.40 & 2.42 & III \\
\hline $\mathbf{3 .}$ & Programme implementation & 2.58 & 2.73 & 2.66 & II \\
\hline $\mathbf{4 .}$ & Fund utilization & 2.67 & 2.70 & 2.69 & I \\
\hline $\mathbf{5 .}$ & Constraints analysis & 1.82 & 1.79 & 1.81 & V \\
\hline $\mathbf{6 .}$ & Selection of farmer representative & 1.65 & 1.38 & 1.52 & VI \\
\hline $\mathbf{7 .}$ & Selection of farmers for training & 1.28 & 1.34 & 1.31 & VII \\
\hline & & \multicolumn{3}{|l|}{ (Maximum Obtainable Score -3$)$} \\
\hline
\end{tabular}


Table.4 Involvement in formulation of programme

\begin{tabular}{|c|c|c|c|c|c|}
\hline \multirow{2}{*}{$\begin{array}{l}\text { S. } \\
\text { No. }\end{array}$} & \multirow[t]{2}{*}{ Programme formulation } & \multicolumn{3}{|l|}{ Mean Score } & \multirow[t]{2}{*}{ Rank } \\
\hline & & $\begin{array}{l}\text { Sundargarh } \\
(\mathrm{n}=96)\end{array}$ & $\begin{array}{l}\text { Keonjhar } \\
(\mathrm{n}=96)\end{array}$ & $\begin{array}{l}\text { Pooled score } \\
(n=192)\end{array}$ & \\
\hline 1. & Participate in PRA exercise & 0.74 & 0.95 & 0.85 & VI \\
\hline 2. & Discussion on the needs of the people & 1.89 & 1.98 & 1.94 & III \\
\hline 3. & Problem diagnosis & 1.92 & 2.01 & 1.97 & II \\
\hline 4. & $\begin{array}{l}\text { Participate in prioritization of the } \\
\text { problems }\end{array}$ & 1.79 & 1.65 & 1.72 & IV \\
\hline 5. & Identify interventions & 2.13 & 2.04 & 2.09 & I \\
\hline 6. & Developing own Programme & 0.41 & 0.65 & 0.53 & VIII \\
\hline 7. & Programme for Govt. land & 0.93 & 0.87 & 0.90 & $\mathrm{~V}$ \\
\hline 8. & $\begin{array}{l}\text { Assist in preparing consolidated water } \\
\text { shed plan }\end{array}$ & 0.83 & 0.68 & 0.76 & VII \\
\hline
\end{tabular}

(Maximum Obtainable Score - 3)

Table.5 Involvement in implementation of programme

\begin{tabular}{|c|c|c|c|c|c|}
\hline \multirow{2}{*}{$\begin{array}{l}\text { S. } \\
\text { No. }\end{array}$} & \multirow[t]{2}{*}{ Implementation } & \multicolumn{3}{|l|}{ Mean Score } & \multirow[t]{2}{*}{ Rank } \\
\hline & & $\begin{array}{l}\text { Sundargarh } \\
(\mathrm{n}=96)\end{array}$ & $\begin{array}{l}\text { Keonjhar } \\
(\mathbf{n}=96)\end{array}$ & $\begin{array}{l}\text { Pooled score } \\
(n=192)\end{array}$ & \\
\hline 1. & $\begin{array}{l}\text { Undertaking activities as per the } \\
\text { approved programme }\end{array}$ & 2.78 & 2.66 & 2.72 & I \\
\hline 2. & Arrangement of required Inputs & 2.43 & 2.46 & 2.45 & II \\
\hline 3. & Timely reporting of the progress of work & 1.40 & 1.67 & 1.54 & $\mathrm{~V}$ \\
\hline 4. & Reviewing progress of work time to time & 1.82 & 1.71 & 1.77 & III \\
\hline 5. & Assist Project personnel in evaluation & 1.82 & 1.71 & 1.77 & III \\
\hline 6. & Participate in management of evaluation & 0.72 & 0.57 & 0.65 & VIII \\
\hline 7. & Plead for refinement / modification & 1.32 & 1.41 & 1.37 & VI \\
\hline 8. & Keeping records of each activity & 1.77 & 1.70 & 1.74 & IV \\
\hline 9. & Discuss on post projects activities & 0.53 & 0.71 & 0.62 & IX \\
\hline
\end{tabular}

(Maximum Obtainable Score-3)

Table.6 Involvement in monitoring and evaluation activities

\begin{tabular}{|l|l|l|l|l|l|}
\hline $\begin{array}{l}\text { S. } \\
\text { No. }\end{array}$ & Monitoring and evaluation & \multicolumn{2}{|l|}{ Mean Score } & Rank \\
\cline { 3 - 5 } & & $\begin{array}{l}\text { Sundargarh } \\
(\mathbf{n = 9 6})\end{array}$ & $\begin{array}{l}\text { Keonjhar } \\
(\mathbf{n = 9 6})\end{array}$ & $\begin{array}{l}\text { Pooled score } \\
(\mathbf{n = 1 9 2})\end{array}$ & \\
\hline 1. & Consultation with WDT & 2.58 & 2.43 & 2.51 & I \\
\hline 2. & Arrangement of additional inputs & 2.03 & 2.12 & 2.07 & II \\
\hline 3. & Planning for crop diversification & 1.28 & 1.38 & 1.34 & V \\
\hline 4. & Introduction of new technologies & 1.92 & 1.89 & 1.91 & III \\
\hline 5. & Maintenance of records & 2.19 & 1.94 & 2.07 & II \\
\hline 6. & Evaluating the progress of work & 1.19 & 0.99 & 1.10 & VI \\
\hline 7. & Giving suggestions & 1.47 & 1.70 & 1.59 & IV \\
\hline
\end{tabular}

(Maximum Obtainable Score-3) 
Table.7 Comparative analysis of the involvement

\begin{tabular}{|c|c|c|c|c|c|c|}
\hline \multirow{2}{*}{$\begin{array}{l}\text { S. } \\
\text { No. }\end{array}$} & \multirow[t]{2}{*}{ Involvement } & \multicolumn{3}{|l|}{ Mean Score } & \multirow{2}{*}{$\begin{array}{l}\text { Pooled } \\
\text { mean score } \\
(n=192)\end{array}$} & \multirow{2}{*}{$\begin{array}{l}\text { Gap } \\
(\%)\end{array}$} \\
\hline & & $\begin{array}{l}\text { Sundargarh } \\
(\mathrm{n}=96)\end{array}$ & $\begin{array}{l}\text { Keonjhar } \\
(\mathrm{n}=96)\end{array}$ & $\begin{array}{l}\text { Diff } \\
(\%)\end{array}$ & & \\
\hline 1. & Project personnel & 2.15 & 2.21 & 2.71 & 2.18 & 27.33 \\
\hline 2. & Watershed activities & 1.83 & 1.86 & 1.61 & 1.85 & 38.33 \\
\hline 3. & Decision making & 2.07 & 2.06 & 0.48 & 2.07 & 31.00 \\
\hline 4. & Programme formulation & 1.34 & 1.35 & 0.74 & 1.35 & 55.00 \\
\hline 5. & Programme implementation & 1.55 & 1.53 & 1.29 & 1.53 & 49.00 \\
\hline 6. & Utilisation of funds & 1.73 & 1.67 & 3.47 & 1.70 & 43.33 \\
\hline 7. & Monitoring and evaluation & 1.80 & 1.77 & 1.67 & 1.79 & 40.33 \\
\hline 8. & Freedom in implementation & 1.86 & 1.91 & 2.62 & 1.89 & 37.00 \\
\hline
\end{tabular}

Table.8 Path analysis of socio-economic attributes influencing involvement

\begin{tabular}{|c|c|c|c|c|c|c|c|}
\hline \multirow{2}{*}{$\begin{array}{l}\text { S. } \\
\text { No. }\end{array}$} & \multirow[t]{2}{*}{ Attribute } & \multirow{2}{*}{$\begin{array}{l}\text { Total } \\
\text { effect }\end{array}$} & \multirow{2}{*}{$\begin{array}{l}\text { Total } \\
\text { direct } \\
\text { effect }\end{array}$} & \multirow{2}{*}{$\begin{array}{l}\text { Total } \\
\text { indirect } \\
\text { effect }\end{array}$} & \multicolumn{3}{|c|}{ Substantial effect } \\
\hline & & & & & I & II & III \\
\hline $\mathbf{X}_{1}$ & Age & -0.523 & -0.230 & -0.293 & $0.142 \mathrm{X}_{7}$ & $0.136 \mathrm{X}_{2}$ & $0.105 \mathrm{X}_{12}$ \\
\hline $\mathbf{X}_{2}$ & Education & 0.723 & 0.214 & 0.509 & $0.137 \mathrm{X}_{8}$ & $-0.112 \mathrm{X}_{10}$ & $-0.059 \mathrm{X}_{9}$ \\
\hline $\mathbf{X}_{3}$ & Family type & 0.243 & -0.059 & 0.302 & $-0.102 \mathrm{X}_{10}$ & $0.086 \mathrm{X}_{1}$ & $-0.042 \mathrm{X}_{5}$ \\
\hline $\mathbf{X}_{4}$ & Family type & 0.366 & 0.098 & 0.268 & $-0.124 X_{12}$ & $-0.172 \mathrm{X}_{8}$ & $-0.074 X_{1}$ \\
\hline $\mathbf{X}_{5}$ & House type & -0.514 & -0.221 & -0.293 & $-0.223 \mathrm{X}_{12}$ & $-0.172 \mathrm{X}_{8}$ & $-0.074 X_{1}$ \\
\hline$X_{6}$ & Occupation & -0.514 & -0.3 .80 & -0.134 & $-0.196 \mathrm{X}_{1}$ & $0.104 X_{3}$ & $-0.023 \mathrm{X}_{8}$ \\
\hline $\mathbf{X}_{7}$ & Annual income & -0.402 & -0.219 & -0.183 & $-0.177 \mathrm{X}_{9}$ & $0.089 \mathrm{X}$ & $0.035 \mathrm{X}$ \\
\hline $\mathbf{X}_{8}$ & Holding size & 0.368 & -0.509 & 0.958 & $-0.556 X_{3}$ & $0.367 \mathrm{X}_{5}$ & $-0.142 X_{12}$ \\
\hline$X_{9}$ & $\begin{array}{l}\text { Possession of } \\
\text { livestock }\end{array}$ & -0.016 & -0.202 & 0.186 & $-0.276 \mathrm{X}_{6}$ & $-0.150 X_{8}$ & $-0.045 X_{2}$ \\
\hline $\mathbf{X}_{10}$ & $\begin{array}{l}\text { Possession of } \\
\text { Agril. } \\
\text { Implements }\end{array}$ & -0.576 & -0.220 & -0.356 & $-0.167 X_{5}$ & $0.082 \mathrm{X}_{4}$ & $0.026 \mathrm{X}_{3}$ \\
\hline$X_{11}$ & $\begin{array}{l}\text { Social } \\
\text { participation }\end{array}$ & -0.514 & -0.227 & -0.287 & $0.173 \mathrm{X}_{8}$ & -0.143 & $-0.034 X_{1}$ \\
\hline$X_{12}$ & $\begin{array}{l}\text { Extension } \\
\text { contact }\end{array}$ & 0.513 & 0.180 & 0.333 & $-0.147 X_{11}$ & $0.113 \mathrm{X}_{9}$ & $0.035 \mathrm{X}_{8}$ \\
\hline
\end{tabular}

Residual effect: 0.033

Highest immediate effect: Holding size 
Path analysis was made to decompose the socio-economic attributes of the respondents into direct, indirect and residual effects. The analysis indicate that the educational background of the respondents had exhibited highest direct effect followed by extension contact. Similarly holding size had exhibited highest indirect effect followed by education, extension contact, family type, family size and possession of livestock. The variable education had association ships with as many as six variables. It is therefore concluded that the variable holding size channelized through education, social participation, house type, possession of livestock, occupation and extension contact could able to accelerate the involvement of the respondents in various watershed activities. The residual effect being 0.033 inferred that $3.30 \%$ of the variation in this relation could not be explained.

The Government of India has implemented nationwide massive and well-designed Watershed Development Programme incorporating all possible factors for effective implementation. The project personnel has also been sufficiently trained on various watershed activities. The guideline developed for effective implementation of the programme has emphasized for the active involvement of the watershed people including women.

The watershed women expressed favourable opinion for the involvement of project personnel working at field level. Better involvement of watershed women were observed in programme development and fund utilization.

Less involvement observed on developing own programme, decisions on post project activities, monitoring and evaluation of progress, decision making process, record keeping, input management and optimum use of created assets indicate that watershed women simply were implementing the programme as planned by the project personnel.

It is therefore suggested that the District Advisory Committee and Project Implementation Committee (PIA) monitoring the programme have to sensitize both the project personnel and watershed women for their active involvement enabling them to develop adequate programme and actively involved in all the activities so that they will be empowered with employment and income generation.

\section{References}

Dadheech, B.S., Sisodia, S.S. and Sharma, C. (2008),Factors affecting Farmer's Participation in Watershed development activities Indian Res. J. Ext. Edu.8 (1):69-70.

Jaiswal, N.K and Punduare, A.P., Jaiswal, A.K. (1985). People participation in watershed management - A case study, Journal of rural development; 5(2):661-705.

Oswal, M. C. (1999). Watershed Management, Associated Publishing Agriculture, New, Delhi, pp- 23.

Pandey, N. K. and Singh, S.K (2014). Participation Pattern of Rural People in Watershed Development Programme in Haryana State,Indian Res. J. Ext. Edu., 14 (3):39-44.

Patel, V.M., Patel, A.J. and, Patel, J.K.(2013).,Impact of Watershed crop production Technology on Adoption level of Beneficiaries and Non Beneficiaries Framers, Gujrat Journal of Extension Education, vol 24, Dec, pp 80-83.

Sharma, R., Meena .B.S and Chauhan, J.,J. (2008) Impact of Participatory Approach in Management of Watershed Practices in Jammu, Indian 
Res. J. Ext. Edu., 8 (1):19-21.

(1and 2):42-44.

Singh, R.A., Sharma, V.K. and Pal, S.B. Thomas, C.G. (2010). Land Husbandry and (2013).,Watershed based frontline demonstration is a path of prosperity to Bundelkhand farm families.,Agriculture Update.Hind Agricultural and Training update, 8 Watershed Management: People's participation in watershed planning, Kalyani Publishers, Ludhiana, India, pp 21-27

\section{How to cite this article:}

Pati, J. K. and Das, R. N. 2019. Involvement of Farm Women in Watershed Activities- A Study in Odisha. Int.J.Curr.Microbiol.App.Sci. 8(09): 2097-2104.

doi: https://doi.org/10.20546/ijcmas.2019.809.242 